\title{
THE POSITIVE AND NEGATIVE EFFECT OF SOCIAL MEDIA ON THE YOUTH'S STATE AND NATION DEVELOPMENT
}

\author{
Suhendar \\ Foreign Language High School (STIBA) IEC Jakarta, Indonesia \\ Email: suhendar@stibaiec-jakarta.ac.id
}

APA Citation: Suhendar.(2018. The Positive and Negative Effect of Social Media on the Youth's State and Nation Development. Journal of English Language and literature, 3(2), 115-130.doi: 10.37110/jell.v3i2.56.

Published:01-09-2018

Abstract: Social media mostly provides facilities and applications which make the youth enjoy their time longer in using social media. In relation to which, the objectives of this study are to identify what are the positives and negatives effects of social media on the youth's state and nation development. As for the method used herein is qualitative in nature and the method of collecting data applied herein is by adopting literary approach. Positive impact of social media are among the other things: to keep in touch with the members of family living so far from house or with the relative which have not met for a long time; to use it as teaching and learning sources; to use it as information media; to broaden fraternity networks; to use it as the facility to improve skill and competence; to use it as communication media; and to use it as promotion and business media. Meanwhile negative effect of social media are among the other things are: difficult to socialize with the people surrounding; social media can make somebody only think about him/herself; the lack of working performance; criminal in cyberspace; and pornography. Accordingly, by knowing positive and negative impact of social media the youth can be wiser to use it only for the purpose of developing the state and nation.

Keywords: agent of change, learning sources, developing state and nation, mass media

\section{INTRODUCTION}

According to Crish Garret social media is such a tool, application and communication that facilitates the relationship between one person to another for making communication and social media are considerably the most wanted by users including the teenagers, even under age person has 


\section{Suhendar.}

The Positive and Negative Effect of Social Media on the Youth's State and Nation Development

already private social media account. The existence of social media gives direct effect either positive or negative.

Development of social media is very rapid because all persons can have his/her own media. If for traditional media like newspaper, television or radio, it is automatically required big capital and much manpower in relation to which it is very different with social media. Social media users can easily access it by using internet networks with relatively lower price and can easily do it.

Social media user in the youth environment can give direct impact both positive and negative. Unfortunately, the youth who frequently uses social media can disturb their learning process. Like for example when they are studying they receive a notification of a chat from his friend, it may disturb their studying process. Hence, the youth as the most active user almost use social media every day. Directly the existing message or information available in social media rapidly proliferates in the cycle of youth. Immaturity of thinking process of the youth can give negative impact against bad information through social media. Like what we know, social media constitute the media for the youth to express the freedom of expression either it is in the form of pictures or messages which sometimes misleading.

In respect of which, information proliferating through social media will be followed routinely by the youth which leads to the opinion building in the youth environment. For example, an official account only quotes the page consisting of discussing about the sweetness of making friend relationship, illustration of an ideal boyfriend or girlfriend, and others. Routines of such account to post the message like that, it indirectly leads the focus of youth attentions only concentrates to make a girl friend or boyfriends instead of improving learning process at school.

\section{General View}

Definition of youth is the process of growth and who is psychologically getting emotional development, hence, the youth constitutes human resources of state nation development either recently or in the future who will substitute the previous generation. Youth are the individuals with dynamic characters, even turbulent and optimistic but who do not have stable emotional control. Youth face a period of social and cultural change. There are many definitions of youth, both physical and psychological definitions of who are worthy of being called youth and whether youth are always associated with passion and 
age. According to Taufik Abdulah $(1974 ; 6)$ youth are individuals with dynamic characters, even volatile and optimistic but who do not yet have stable emotional control. Youth face social and cultural changes. In this matter, Princeton defines the word youth in his webster dictionary as " the time of life between childhood and maturity; early maturity; the state of being young or immature or inexperienced; the freshness and vitality characteristic of a young person'. According to WHO in Sarlito Sarwono (2008:9) the age of 10-24 years is classified into young people, while teenager or adolescence is in 10-19 years of age classification. According to Mukhlis (2007:1) "Youth is a generation Youth is a generation whose shoulders are burdened with various expectations, especially from other generations. This is understandable because young people are expected to be the next generation, generations who must fill and carry out sustainable development relay. According to Taufik Abdulah (1974:38) There are several aspects of youth which are viewed from two assumptions: 1 . An appreciation of the process of human development not as a continuum that is continuous but fragmentary, fragmented, and each fragment has its own meaning.

Youth are distinguished from children and parents and each of the fragments represents their own value.
2. An addition to the assumption of insight into life is the position of youth in the direction of life itself. Youth as a subject in life certainly have their own values in supporting and moving together. This can only happen if the behavior of the youth itself is viewed as an interaction in the environment in a broad sense. The main characteristic of this approach encompasses two main elements, namely the environmental or ecological elements as a whole and second, the elements of the objectives that guide the dynamics in the environment. The balance between humans and their environment is a dynamic balance, an interaction that moves. The direction of the movement itself may be in the direction of improvement may also be towards destruction. There are several positions of youth in their accountability for the community structure, including: a. The purity of its idealism b. Courage and Openness in absorbing new values and ideas c. The spirit of devotion d. Spontaneity and dynamics e. Innovation and creativity f. The desire to immediately realize new ideas g. Firmness in promise and the desire to display the independent attitude and personality $h$. There is still a lack of experiences that can reflect opinions, attitudes and actions with the reality. The definition of youth above is more on technical definitions based on age categories while other definitions are more flexible. Where young people / young 


\section{Suhendar.}

The Positive and Negative Effect of Social Media on the Youth's State and Nation Development

generation / youth are those who have a spirit of reform and progressiveness.

Nationalism is an understanding that prioritizes national unity and freedom. Nationalism contains several principles, namely: unity, freedom, equality, personality, and achievement. Nationalism can also be interpreted as a combination of nationality and nationalism. With a high national spirit, concerns about the threat of national integrity will be avoided. According to John Hutchinson (2000:34) Nationalism is more of a cultural phenomenon than a political phenomenon because it is rooted in pro-modern ethnicity and culture. In this viewpoint, the nationalist political movement is a means of regaining ethnic self-esteem as a basic capital to build a countries based on cultural similarities. The spirit of nationality will flow a sense of social solidarity, the spirit of willingness to sacrifice and can foster a spirit of patriotism. A sense of social solidarity will strengthen the national spirit of a nation. According to the Big Indonesian Dictionary in Listiyarti (2007: 26) "nationalism comes from the word national and ism namely nationalism which means the awareness and spirit of love for the homeland, having a nationality, or maintaining national dignity," According to Hitler in Chotib and Djazuli (2007: 24) "nationalism is the attitude and spirit of sacrifice against other nations" Nationalism has several forms according to Retno Listyarti (2007: 28), among others: 1. Nationalism citizenship (civil nationalism) is nationalism where the state gains political truth from active participation of its people. Membership of a nation 19 is voluntary. This form of nationalism was first built by Jean-Jacques Rousseau and became the material of his writing. 2. Ethnic nationalism or ethno-nationalism is where the state gains political truth from the origin or ethnic culture of a society. Membership of a nation is hereditary. 3. Romantic nationalism is a form of ethnic nationalism in which the state gains political truth as a natural thing and is an expression of dancing or race. Romantic nationalism focuses on ethnic culture in accordance with romantic idealism. 4. Cultural nationalism is nationalism where the state manages political truth from a shared culture and is not hereditary such as skin color. State nationalism is a variation of citizenship nationalism which is often combined with ethnic nationalism. .In nationalism nationality is a communion that contributes to the maintenance and strength of the state. 6. Religious nationalism is nationalism where the state gains political legitimacy from religious equality.

A sense of love for the motherland or nationalism is a sense 
of pride, ownership, respect, a sense of respect and a sense of loyalty that is owned by each individual in the country where he lives which is reflected in the behavior of defending his homeland, loves customs or culture in his country by preserving and preserving nature and the environment. A sense of love for the homeland and nation which is summarized in the spirit of patriotism must always be embedded in every heart of the Indonesian people. Moreover, lately the feeling of love for the homeland and nation which is summarized in the spirit of patriotism must always be embedded in every heart of the Indonesian people. Therefore, a sense of love for the homeland needs to be cultivated in the soul of every individual who becomes a citizen of a country or nation so that the common goals of the nation can be achieved.

It is this sense of love for the motherland that encourages individual behavior to build his country with full dedication. Therefore, a sense of love for the motherland needs to be developed in the soul of every individual who becomes a citizen of a country or nation so that the common goals of the nation can be achieved.

\section{METHOD}

The method used is qualitative in nature and the method of collecting data applied herein is by adopting literary approach. In this research, the writer used cross sectional survey which the information data applied herein is collected from library and internet.

\section{FINDING AND DISCUSSION}

Generally, to identify the growth and the age classification of social media user in the world can be seen from the graphs below.

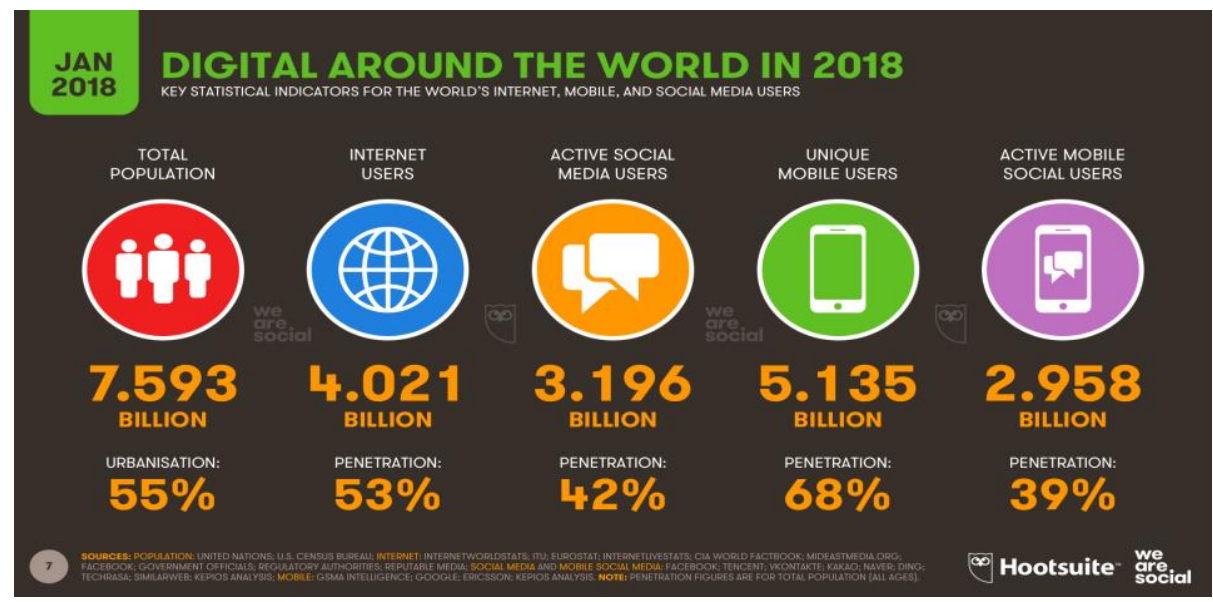




\section{Suhendar.}

The Positive and Negative Effect of Social Media on the Youth's State and Nation Development

Source: Internet

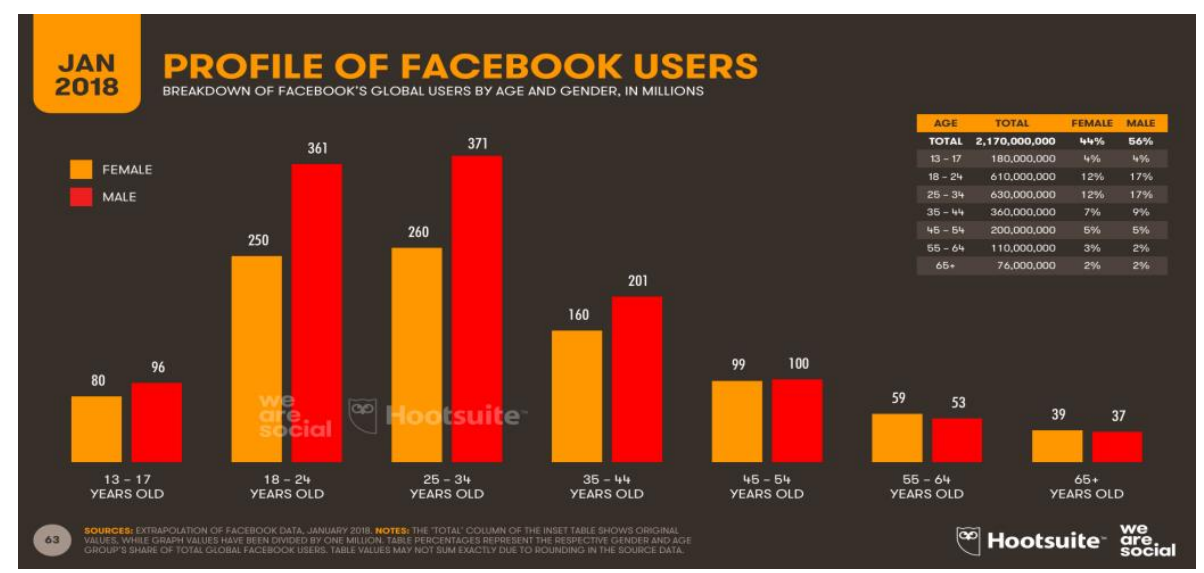

Source: internet

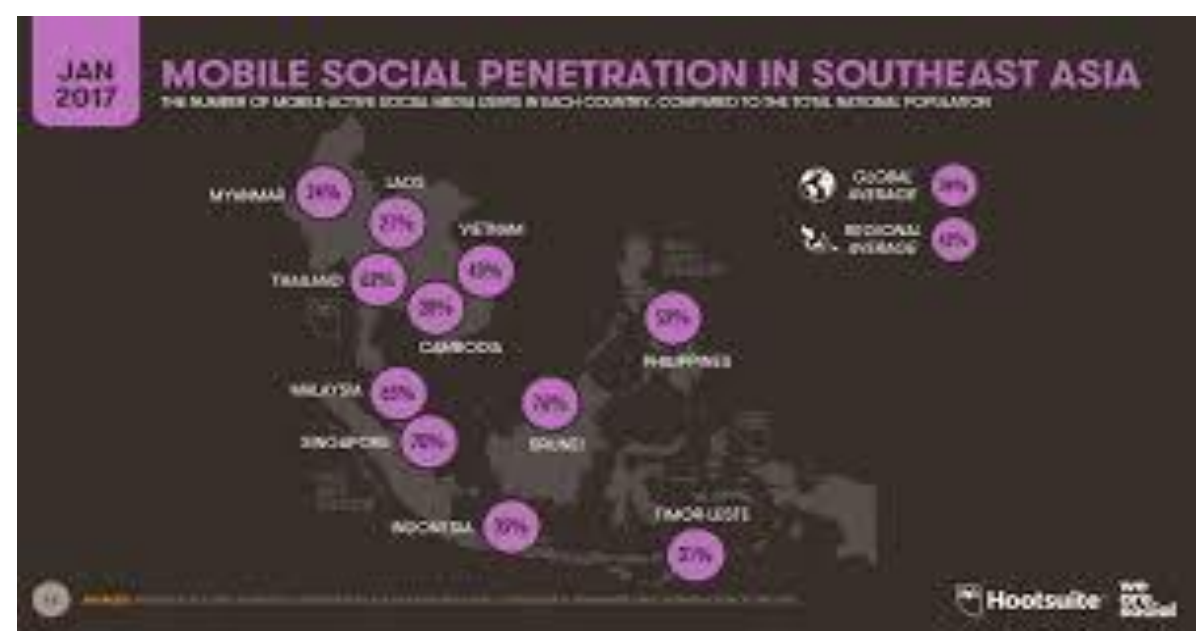

Source: internet 


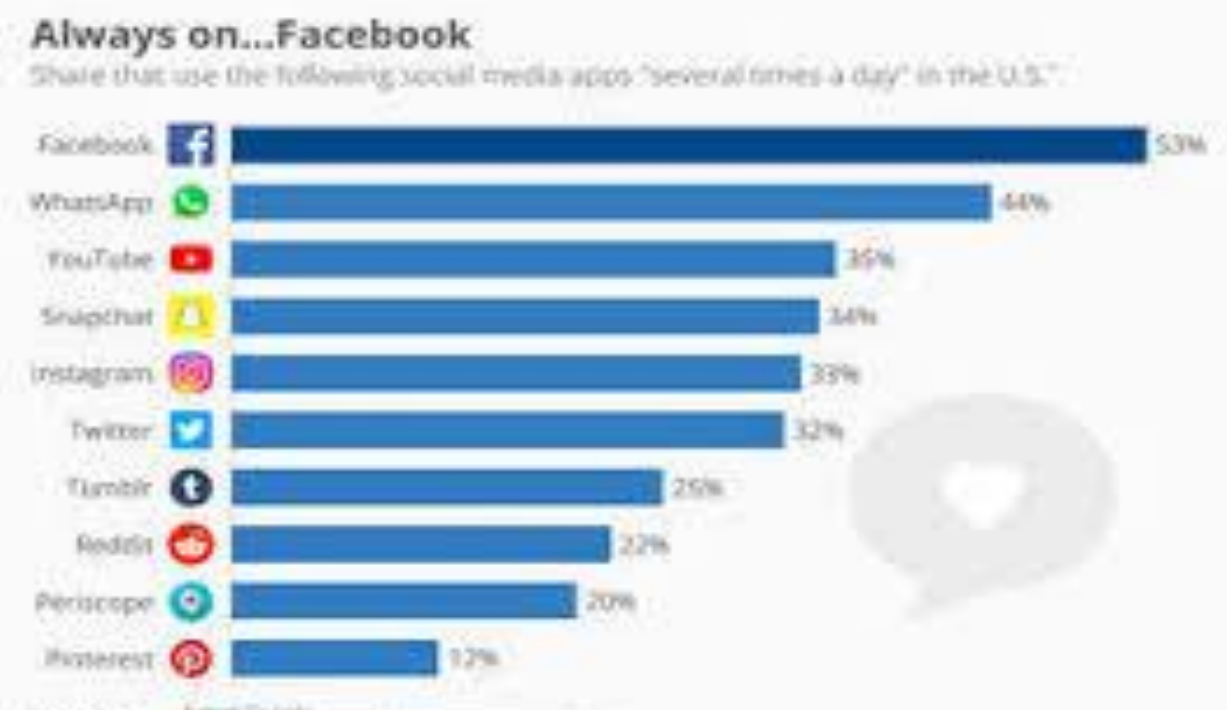

\section{Here are some prominent examples of social media:}

1) Facebook is a popular free social networking website that allows registered users to create profiles, upload photos and video, send messages and keep in touch with friends, family and colleagues. According to statistics from the Nielsen Group, Internet users within the United States spend more time on Facebook than any other website.

2) Twitter is a free microblogging service that allows registered members to broadcast short posts called tweets. Twitter members can broadcast tweets and follow other users' tweets by using multiple platforms and devices.

3) Google+ (pronounced Google plus) is Google's social networking project, designed to replicate the way people interact offline more closely than is the case in other social networking services. The project's slogan is "Real-life sharing rethought for the web."

4) Wikipedia is a free, open content online encyclopedia created through the collaborative effort of a community of users known as Wikipedians. Anyone registered on the site can create an article for publication; registration is not 


\section{Suhendar.}

The Positive and Negative Effect of Social Media on the Youth's State and Nation Development

required to edit articles. Wikipedia was founded in January of 2001.

5) LinkedIn is a social networking site designed specifically for the business community. The goal of the site is to allow registered members to establish and document networks of people they know and trust professionally.

6) Reddit is a social news website and forum where stories are socially curated and promoted by site members. The site is composed of hundreds of sub-communities, known as "subreddits." Each subreddit has a specific topic such as technology, politics or music. Reddit site members, also known as, "redditors," submit content which is then voted upon by other members. The goal is to send well- regarded stories to the top of the site's main thread page.

7) Pinterest is a social curation website for sharing and categorizing images found online. Pinterest requires brief descriptions but the main focus of the site is visual. Clicking on an image will take you to the original source, so, for example, if you click on a picture of a pair of shoes, you might be taken to a site where you can purchase them. An image of blueberry pancakes might take you to the recipe; a picture of a whimsical birdhouse might take you to the instructions.

Brian Solis created the following social media chart, known as the conversation prism, to categorize social sites and services into various types of social media. (See a larger image) 


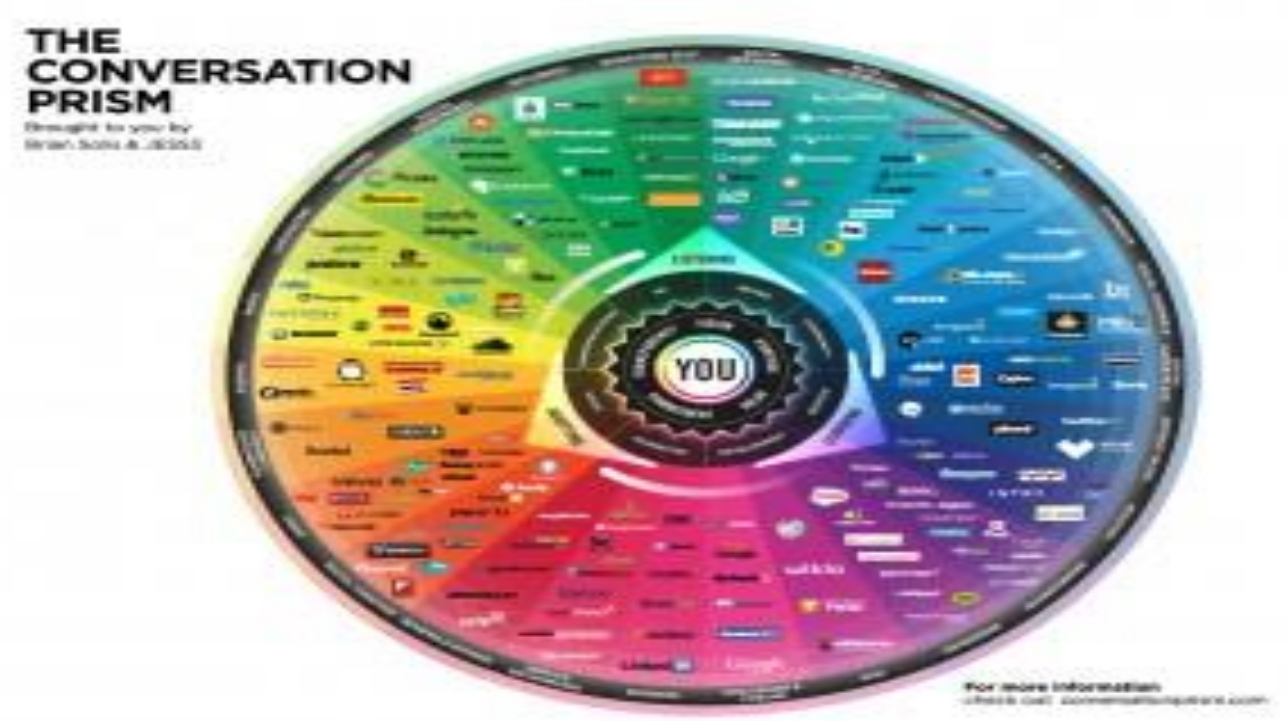

Source: Internet

Social media is becoming an integral part of life online as social websites and applications proliferate. Most traditional online media include social components, such as comment fields for users. In business, social media is used to market products, promote brands, connect to current customers and foster new business.

Social media analytics is the practice of gathering data from blogs and social media websites and analyzing that data to make business decisions. The most common use of social media analytics is to mine customer sentiment to support marketing and customer service activities.

Social media marketing
$(\mathrm{SMM})$ takes advantage of social networking to help a company increase brand exposure and broaden customer reach. The goal is usually to create content compelling enough that users will share it with their social networks.

One of the key components of SMM is social media optimization (SMO). Like search engine optimization (SEO), SMO is a strategy for drawing new and unique visitors to a website. SMO can be done two ways: by adding social media links to content such as RSS feeds and sharing buttons, or by promoting activity through social media via status updates, tweets, or blog posts.

\section{Social CRM (customer} relationship marketing) can be a very powerful business tool. For example, 


\section{Suhendar.}

The Positive and Negative Effect of Social Media on the Youth's State and Nation Development

establishing a Facebook page allows

people who like your brand and the way you conduct business to Like your page, which creates a venue for communication, marketing and networking. Through social media sites, you can follow conversations about your brand for real-time market data and feedback.

From the customer's perspective, social media makes it easy to tell a company and everyone else about their experiences with that company - whether those experiences are good or bad. The business can also respond very quickly to both positive and negative feedback, attend to customer problems and maintain, regain or rebuild customer confidence.

Enterprise social networking allows a company to connect individuals who share similar business interests or activities. Internally, social tools can help employees access information and resources they need to work together effectively and solve business problems. Externally, public social media platforms help an organization stay close to their customers and make it easier to conduct research that they can use to improve business processes and operations.

Social media is also often used for crowdsourcing. Customers can use social networking sites to offer ideas for future products or tweaks to current ones. In IT projects, crowdsourcing usually involves engaging and blending business and IT services from a mix of internal and external providers, sometimes with input from customers and/or the general public.

On the other hand, the integration of social media in the business world can also pose challenges. Social media policies are designed to set expectations for appropriate behavior and ensure that an employee's posts will not expose the company to legal problems or public embarrassment. Such policies include directives for when an employee should identify himself as a representative of the company on a social networking website.

In conclusion, in globalization era nowadays, there are so many social media rapidly growing. The users are not only the adult person but also students and children. Even the young person has been already familiar with social media which is now growing rapidly. Starting from Friendster, later on Facebook, Twitter, Skype, Foursquare, Line, What's App, Path, Instagram, Snapchat and still many others. The effect arising from the utilization of social media are positive and negative as follows: 


\begin{tabular}{|c|c|c|}
\hline $\begin{array}{l}\text { Positive Effect of Social } \\
\text { Media for the youth }\end{array}$ & $\begin{array}{l}\text { Negative effect of social } \\
\text { media for the youth }\end{array}$ & $\begin{array}{c}\text { Advices for the youth to } \\
\text { use social media }\end{array}$ \\
\hline $\begin{array}{l}\text { - To keep in touch with } \\
\text { the members of family } \\
\text { living so far from house } \\
\text { or with the relative } \\
\text { which have not met for } \\
\text { a long time, } \\
\text { - As information media, } \\
\text { - To broaden fraternity } \\
\text { networks, } \\
\text { - To make youth or } \\
\text { teenager to become } \\
\text { friendlier, having full } \\
\text { attention and empathy, } \\
\text { As the facility to } \\
\text { improve skill and } \\
\text { competence, } \\
\text { As communication } \\
\text { media } \\
\text { Data exchanging media } \\
\text { As promotion and } \\
\text { business media }\end{array}$ & $\begin{array}{l}\text { Difficult to } \\
\text { socialize with the } \\
\text { people surrounding } \\
\text { - } \text { Social media can } \\
\text { make the user more } \\
\text { selfish } \\
\text { The loss of formal } \\
\text { language } \\
\text { Lack } \\
\text { performance } \\
\text { The decrease of } \\
\text { personal privacy } \\
\text { Cybercrime } \\
\text { Pornography }\end{array}$ & $\begin{array}{l}\text { - To get knowledge and } \\
\text { understanding } \\
\text { regarding the positive } \\
\text { and negative factors } \\
\text { of using social media; } \\
\text { Should get religious } \\
\text { teaching in order that } \\
\text { they can understand } \\
\text { about the good ways } \\
\text { of making friends } \\
\text { according to religion; } \\
\text { Should get control } \\
\text { from parents in using } \\
\text { social networking } \\
\text { sites in order to } \\
\text { prevent them from } \\
\text { any unexpected } \\
\text { matters; } \\
\text { Should make use of } \\
\text { privacy settings; don't } \\
\text { overshare their } \\
\text { mother's maiden } \\
\text { name or personal } \\
\text { details, such as phone } \\
\text { number or home } \\
\text { address; understand } \\
\text { Should un } \\
\text { that social media sites } \\
\text { is not a popularity } \\
\text { contest; should be } \\
\text { wary of links; don't } \\
\text { link accounts; use a } \\
\text { separate email, and } \\
\text { use strong passwords }\end{array}$ \\
\hline
\end{tabular}

\section{Positive effect:}

1) To keep in touch with the members of family living so far from house or with the relative which have not met for a long time. By using social media, the user can meet family, relative, living separately. This social network is very useful and having a significant rule to reunite the family or relative 


\section{Suhendar.}

The Positive and Negative Effect of Social Media on the Youth's State and Nation Development

living so far and already long time not meeting together.

2) As information media. Up to date information is very easily proliferating through social media networks. It is only several minutes after the event; the user can enjoy such information.

3) To broaden fraternity networks. By using social media network the user can make communication with anybody whomsoever around the world, even with the person whom the user has not recognized yet.

4) To make youth or teenager to become friendlier, having full attention and empathy.

5) As the facility to improve skill and competence. The user may study how to find out the way of good adaptation and socialization with public and manage friend networks.

6) As communication media. Every internet user may communicate with the other users around the world.

7) Data exchanging media. By using internet websites, the user around the world may exchange information one another quickly and chiefly.
8) As promotion and business media. This matter enables the small business player to promote their product and service without expending a lot of costs.

\section{Negative effect:}

1) Difficult to socialize with the people surrounding. This matter is because the social media user is lazy to communicate each other by meeting face to face.

2) Social media can make the user more selfish. They do not realize about surrounding environment as they mostly spend their time in internet.

3) The loss of formal language. Because the social media user frequently use informal language in his/her daily activity.

4) Lack of performance. Employee of a certain company, student using social media when they are working will reduce their working time or their learning time.

5) The decrease of personal privacy. In social media the user is free to write and to share anything. Many often the social media user may publish information which 
should not be disclosed to public domain.

6) Cybercrime. Cybercrime varies, some of which are: carding, hacking, cracking, phishing, and spamming.

7) Pornography. The capacity of internet may also provide pornographic contain. This is very dangerous because may decrease morality and good attitude of the youth.

The above explanations can be simplified by the following picture;

\section{Advices for parents to control the youth in using social media}

From the description mentioned hereinabove there are some tips for the parents to control the youth, namely the parents should conduct the following matters:

1) Give the youth knowledge and understanding regarding the positive and negative factors of using social media sites, so that the abuses of social media can be avoided.

2) Give the youth religious teaching in order that they can understand about the good ways of making friends according to religion, so that they will not be easily tempted by any seduction, enticement, hopes and persuasion from the person who have not been recognized yet.

3) Always pay attention to the youth amid their activity working in their offices. Parents are forcefully required to control the youth in using social networking sites in order to prevent them from any unexpected matters. In addition parents should know some modus which frequently uses by the deceiver.

4) Make use of privacy settings. Read the site's privacy policy and use its privacy and security settings to control who can see the youth personal information. Facebook, for example, offers controls over who can see your basic or full profile, your posts and photos and what appears in your timeline.

5) Don't overshare. Parents should make sure that the youth do not overshare their mother's maiden name or personal details, such as phone number or home address. Avoid posting photos of home that make it easy to identify where you live.

6) Make sure that social media sites is not a popularity contest. Parents should inform the youth not to accept every 


\section{Suhendar.}

The Positive and Negative Effect of Social Media on the Youth's State and Nation Development

friend or follower request them, get - only connect with people they know in real life or whose identity they know is genuine. Criminals create fake online accounts in order to befriend others and harvest personal information. Where possible always follow social media accounts that have a white tick in a light blue circle next to their name. This means they are an officially verified account.

7) Be wary of links. Avoid clicking on links in messages, tweets, posts, and online advertising. These may be links to viruses or other forms of malicious content.

8) Don't link accounts. Many websites and apps give the option to ' $\log$ in with Facebook', rather than creating a separate account. But by doing this, the youth's social network may share all the information it holds about them, including the date and place of birth, email address and employment details, along with photos. Furthermore, with just one log-in for multiple sites, if one site is hacked, then all the youth's accounts are compromised too.

9) Use a separate email. On that note, parent can inform the youth to go one step further and create a separate email account to use with each social network. That way, the youth main email account is protected from any spam or phishing email the youth may receive.

10) Use strong passwords. It is better to use a separate password for each social account.

Make it at least eight digits long and a combination of upper and lower case letters, numbers and symbols.

\section{CONCLUSION}

Progressively, the world has changed and it will continuously change. The distance between the regions even between the countries has been closer because of social networking sites. Nowadays the world has changed, every person may share live picture to another, everybody can speak to another and can see the picture to whom he/she is talking to directly wherever he/she is available.

\section{Internet-based information} technology has been developed rapidly in Indonesia; the most wanted internet-based product nowadays is social media networks in the forms of facebook and twitter. By these social networking sites the user can 
communicate with his/her old or new friends from around the world.

The existence of social media cannot however be avoided, most of the youths and teenagers have been familiar with such social media networks. It does not only happen to urban society but it also happens in the village society.

The rapid growth of such social networking sites has automatically positive and negative effect, therefore it is important to make such a supervisory system and guidance for them in order that negative effect of which may be avoided the positive effect of which can be more considerably achieved.

\section{BIBLIOGRAPHY}

Barnes, A., \& Laird, C. (2012). The effects of social media on children. Retrieved on June 30, 2015 from website: http://sites.ewu.edu/cmst496stafford/2012/06/06/the-effects-ofsocial-media-on-children/

Boyd, D. M., \& Ellison, N. B. (2007). Social network sites: Definition, history, and scholarship. Journal of Computer-Mediated Communication, 13(1), 210- 230.

Bryant, J. A., Sanders-Jackson, A., \& Smallwood, A. (2006). IMing, text messaging, and adolescent social networks. Journal of ComputerMediated Communication, 11(2), 577-592.

Carroll, J. A., \& Kirkpatrick, R. L. (2011). Impact of social media on adolescent behavioral health. Oakland, CA: California Adolescent Health Collaborative.

Coyle, C., \& Vaughn, H. (2008). Social networking: Communication revolution or evolution? Bell Labs Technical Journal, 13(2), 13-17.

Duncan, D. K., Hoekstra, A. R., \& Wilcox, B. R. (2012). Digital devices, distraction, and student performance: Does in class cell phone use reduce learning? Astronomy Education Review, 11, 010108, 1-4.

Giles, G., \& Price, R. (2008). Adolescent computer use: Approach, avoidance, and parental control. Australian Journal of Psychology, 60(2), 63-71.

Gok, T. (2015). The positive and negative effects of digital technologies on students' learning. In Sahin, I., Kiray, A., \& Alan, S. (Eds.), Proceeding Book of International Conference on Education in Mathematics, Science \& Technology (ICEMST), 215-219, Antalya.

Hakoyama, M., \& Hakoyama, S. (2011). The impact of cell phone 


\section{Suhendar.}

The Positive and Negative Effect of Social Media on the Youth's State and Nation

Development

use on social networking and development among college students. The American Association of Behavioral and Social Sciences Journal, 15, 1-20.

Junco, R., Merson, D., \& Salter, D. W. (2010). The effect of gender, ethnicity, and income on college students' use of communication technologies. Cyberpsychology, Behavior, and Social Networking, 13(6), 619627.

Kalpidou, M., Costin, D., \& Morris, J. (2011). The relationship between Facebook and the well-being of undergraduate college students. Cyberpsychology, Behavior \& Social Networking, 14(4), 183189.

Nehls, K., \& Smith, B. D. (2014). The role of facebook in fostering transfer student integration. Journal of Student Affairs Research and Practice, 51(4), 392-406.
O’ Keeffe, G. S., \& Clarke-Pearson, K. (2011). The impact of social media on children, adolescent, and families. Pediatrics,127(4), 800-804.

Ophir, E., Nass, C., \& Wagner, A. D. (2009). Cognitive control in media multi-taskers. Proceeding of the National Academy of Sciences, 106(33), 15583-15587.

Raacke, J., \& Bonds-Raacke, J. (2008). MySpace and facebook: Applying the uses and gratifications theory to exploring friend-networking sites. CyberPsychology \& Behavior, 11(2), 169-174.

Rafferty, F. (2009). Boys should be boys-is it that simple? Education Journal, 116, 32-33.

https://www.saga.co.uk/magazine/tech nology/internet/communications/u se-social-media-websites-safely 